\title{
New laws to reduce tobacco smoking changed attitudes to the problem, but not the percentage of smokers
}

\author{
Dagmara Opoczyńska-Świeżewska', Filip Raciborski, Bolesław Krzysztof Samoliński ${ }^{1}$ \\ ${ }^{1}$ Department of Prevention of Environmental Hazards and Allergology, Medical University of Warsaw, Poland \\ Opoczyńska-Świeżewska D, Raciborski F, Samoliński BK. New laws to reduce tobacco smoking changed attitudes to the problem, but not \\ the percentage of smokers. Ann Agric Env Med. 2018; 25(3): 546-551. doi: 10.26444/aaem/76703
}

\begin{abstract}
Introduction. The epidemic of tobacco smoking remains one of the most important challenges in public health. It is associated with premature death. For this reason, the Act of 9 November 1995 on the Protection of Public Health against the Effects of Use of Tobacco and Tobacco Products, as amended on 15 November 2010, implemented significant additional restrictions on smoking in public places.

Objective. The objective of this study is evaluation of the impact of smoking regulations on social behaviour and attitude to the legal forms of tobacco control, due to the new smoke-free policy.

Materials and method. A secondary statistical analysis of third party data was used in the study. The material was obtained from the Public Opinion Research Centre. Polls are conducted among representative samples of about 1,000 adult inhabitants of Poland. The studies on cigarette smoking were carried out in 3 editions $(2010,2011,2012)$.

Results. The collected data on tobacco smoking before and after implementation of the Act show that the number of smokers remained at a comparable level - about $30 \%(p=0.891)$.

Between 2010-2012, an increase was observed in the percentage of people supporting the smoking ban in public places. The total number of people who definitely or rather supported the smoking ban increased from $75.6 \%$ in 2010 to $85.0 \%$ in $2012(p<0.001)$.

Conclusions. The restrictive smoking ban in public places implemented in 2010 did not have an impact on the number of smokers in the studied time interval, although an increase in the number of people supporting the smoking ban in public places was observed.
\end{abstract}

\section{Key words}

tobacco cessation, smoke-free policy, smoking epidemiology, public health

\section{INTRODUCTION}

Tobacco smoking worldwide and in Poland. Tobacco smoke contains a mixture of more than 7,000 (mostly toxic) chemicals, of which about 70 can cause cancer [1]. The first epidemiological evidence confirming the relationship between smoking and cancer was recorded in the 1920s [2].

The epidemic of tobacco smoking remains one of the most important contemporary challenges in public health. It constitutes one of the major factors associated with premature death, responsible for about $9 \%$ of deaths globally [3], including 18\% of deaths in high-income countries, $11 \%$ in middle-income countries and $4 \%$ in low-income countries [4]. These rates are expected to increase due to the recorded growing number of smokers in low- and middle-income countries. According to the World Health Organisation (WHO), tobacco use kills nearly 6 million people each year [3]. More than 0.6 million of them are exposed to secondhand smoke [5].

Data from the WHO show that 1.6 million people in Europe die from tobacco smoking each year [6]. In the last 50 years, about 32 million Europeans (27 million men and

Address for correspondence: Dagmara Opoczyńska-Świeżewska, Department of Prevention of Environmental Hazards and Allergology, Medical University of Warsaw

e-mail:d.opoczynska@gmail.com

Received: 9 December 2015; accepted: 17 February 2017; first published on July, 152017
5 million women) in 28 Member States have died due to smoking-related diseases. More than half of those deaths occurred in people aged 35-69 [7]. It is also estimated that about 13 million Europeans suffer from chronic smokingrelated diseases [6], such as respiratory system diseases, circulatory system diseases and cancer [8].

The risk of developing smoking-related diseases increases with the increasing number of cigarettes smoked and cumulative dose of smoking [9]. In 2000 in Poland, tobacco smoking caused 69,000 deaths, $60 \%$ of which were premature deaths of individuals aged 35-69 [10].

According to the Centres for Disease Control and Prevention [11], smoking can cause negative health effects. It is estimated that smoking can increase the risk of:

- ischaemic heart disease (2-4 times);

- stroke (2-4 times);

- lung cancer in men (23 times);

- lung cancer in women (13 times);

- death caused by chronic obstructive pulmonary disease (e.g. chronic bronchitis and emphysema) (12-13 times).

Quitting smoking lowers the number of smoking-related diseases, including deaths. Studies prove that a smoker's age plays an important role in smoking cessation. The greatest health benefits are observed among smokers who quit completely before the age of 30 . It is estimated that they would die at the same age as non-smokers. People who will quit smoking before the age of 40 , would regain 9 out of the 
10 years they would lose if they had continued. Nevertheless, quitting smoking even at the age of 50 would prolong the lifespan by 6 years, while quitting at the age of 60 , by 4 years, compared to a person who continued smoking $[7,12]$.

It is estimated that the global prevalence of smoking is about $31.1 \%$ of men and $6.2 \%$ of women. The highest percentage of smokers is recorded in low- and middle-income countries [13]. The 2009-2010 Global Adult Tobacco Survey (GATS) shows that $36.9 \%$ of Polish men and $24.4 \%$ of Polish women aged 15 years and older smoke $[9,10,14,15]$.

Situation in the EU - smoking ban in other Member States. The 2013 report by the European Commission notes that all Member States have laws that protect citizens from exposure to tobacco smoke in workplaces, enclosed public places, public transport, and other public places. However, the scope of these regulations differs in the various countries. In most countries, the strictest regulations concern educational institutions, facilities providing services to children, public transport, and the health care sector [16]. New national laws were often implemented after adopting the WHO Framework Convention on Tobacco Control (FCTC) and the Council recommendation on smoke-free environments [16].

Many Member States expanded the scope of their antismoking laws, mainly in the gastronomy sector. In 2004, Ireland was the first European country to implement a comprehensive ban on smoking in enclosed public places, public transport, workplaces, restaurants, bars, and other public places. In subsequent years, similar measures have been taken by such countries as the United Kingdom, Slovakia, Greece, the Czech Republic, Estonia and Poland [16].

The Polish policy to reduce smoking. In 1995, the first Polish Act to prevent the effects of tobacco use was passed [17]. The Act of 9 November 1995 on the Protection of Public Health against the Effects of Use of Tobacco and Tobacco Products introduced significant restrictions on smoking in the workplace, schools and health care facilities. In educational institutions and health care facilities tobacco smoking was still permitted in designated areas. The Act also allowed customers of catering establishments to smoke at designated smoking tables in rooms where food or drink were served for consumption. This Act did not protect non-smokers as no technical measures were taken to ensure appropriate smoke-free conditions elsewhere.

One of the main documents shaping the Polish antismoking policy is the National Health Programme 20072015. Its operational Directive No. 1 is to prevent smoking from spreading further. The most important and expected results possible to be achieved by 2015 included a decrease in the number of the cigarettes smoked daily (1-3\% annually), reducing smoking among children and teenagers, and placing emphasis on training sessions for people engaged in tobacco-use prevention in schools and educational and cultural institutions $[18,19]$.

The aforementioned provisions and the FCTC resolutions resulted in the creation of smoke-free environments for Polish citizens. For this reason, the Act of 9 November 1995 on the Protection of Public Health against the Effects of Use of Tobacco and Tobacco Products was amended. On 15 November 2010, significant additional restrictions on smoking in public places were implemented. The law was extended to include the following in smoke-free areas:
- health care entities and facilities providing health services;

- public areas in culture and recreation facilities;

- public transport and establishments serving the needs of travellers;

- public transport stops;

- public playgrounds for children.

A significant change also included a smoking ban in catering and entertainment facilities. The Act still allowed owners to designate special areas for smoking [17].

Similar solutions are used in other Member States (e.g. Belgium, Finland, Italy, Sweden), where smoking is permitted in specially adapted rooms. Most Member States implemented a smoking ban in educational institutions and on public transport. Half of the Member States banned smoking completely in health care facilities. The biggest differences concerned the ban in workplaces and public places, including catering and entertainment facilities. Smoking is completely banned in such countries as: Bulgaria, Cyprus, Spain, Ireland, Lithuania, Latvia, Malta and Hungary [16].

\section{OBJECTIVE}

The objective of this study is evaluation of the impact of smoking regulations on social behaviour and attitude to the legal forms of tobacco control, due to the Act of 9 November 1995 on the Protection of Public Health against the Effects of Use of Tobacco and Tobacco Products, amended in 2010.

\section{MATERIALS AND METHOD}

A secondary data analysis was used in the study as a primary research method. Secondary data analysis is a statistical method where data was collected by another person for another primary purpose (e.g. medical registers). This method allows the performance of a high-impact study reducing the time and resources needed $[20,21]$.

The material (the data base) was obtained from the Public Opinion Research Centre [CBOS - Centrum Badania Opinii Społecznej], which carries out periodic survey research regarding public issues, including tobacco smoking. Polls are conducted among representative samples of about 1,000 adult Polish inhabitants (aged 18 years and older). The studies on cigarette smoking were carried out in 3 editions: February 2010, May 2011, and July 2012. A total of 3,170 adult Poles participated in the studies $(2010-1,021$, in $2011-1,189$, in 2012 - 960).

Questionnaire-based interviews were conducted by qualified interviewers at the respondent's home. The questionnaires consisted of about 160 closed questions regarding, among others, health issues, paid employment and incomes, and current events, such as presidential and parliamentary elections, and sports events.

For the needs of this work, the answers to the following questions were analysed:

- Do you smoke?

- Do you generally support the smoking ban in public places or not?

Additional variables, such as gender, age and education were also taken into consideration. 
Statistical analysis was conducted with IBM SPSS software (ver. 22). The statistical significance level was $\leq 0.05$.

\section{RESULTS}

Impact of the Act on the number of smokers in Poland. The collected data on tobacco smoking before and after implementation of the Act show that the percentage of smokers between February 2010 - July 2012 remained at a comparable level - about 30\% (2010 - 30.3\%; 2011- 29.8\%; $2012-30.7 \%)$. There were no statistically significant differences between particular survey editions $(\mathrm{p}=0.891)$. At the turn of 2010 and 2011, a decrease from $40.3 \%$ to $35.1 \%$ was observed in the group of male smokers, and then in 2012 it increased to $40.0 \%$. For women, an opposite trend occurred. In $2010,21.4 \%$ of women declared smoking cigarettes, in $2011-25.0 \%$, and in $2012-22.5 \%$. The prevalence of regular smokers in 2010-2012 remained at a comparable level - about $25 \%$ (2010 - 25.4\%; $2011-24.3 \% ; 2012-25.3 \%)$, whereas the percentage of occasional smokers slightly increased from $4.8 \%$ in 2010 to $5.4 \%$ in 2012. (Fig. 1). Among the smokers, those who smoked regularly constituted $84.1 \%$ in $2010,81.6 \%$ in 2011 , and $82.4 \%$ in 2012 . This remained a prevailing attitude among both men and women in all analysed years.

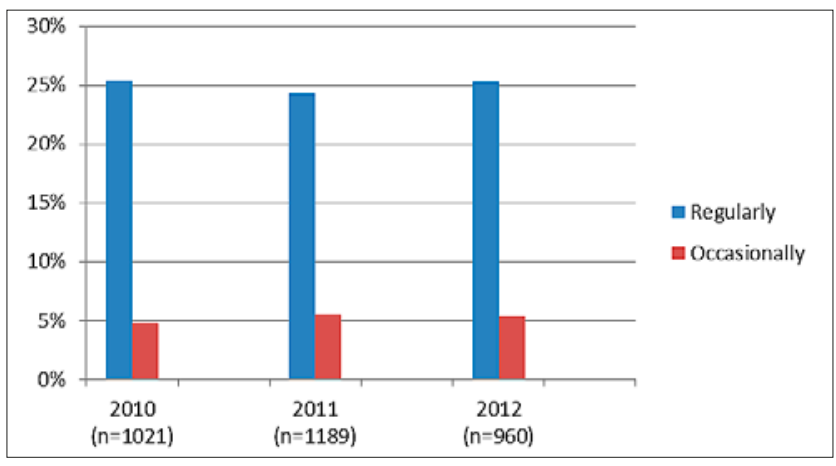

Figure 1. Percentage of people who smoked regularly and on special occasions, and occasionally, among the population in 2010-2012

In 2010 and 2012, the highest percentage of people who smoked regularly and occasionally was recorded in the age group $35-44$ years at $37.8 \%$ and $39.6 \%$, respectively. In 2011 , in the age group $45-54$ years, it was $42.8 \%$. The lowest percentage of smokers in all analysed years was observed in the age group 65 years and older (Tab. 1).

In all 3 analysed years, the highest percentage of smokers was recorded among respondents with vocational education at $40.4 \%, 41.3 \%, 36.3 \%$, respectively. The smallest number of smokers was in the group of people with a university degree: in $2010-22.6 \%, 2011-18.8 \%, 2012-20.0 \%$.

In the period studied, education had a statistically significant impact on the results $(\mathrm{p}<0.001)$ (Tab. 1).

In 2010, the highest percentage of smokers was recorded in cities with 100,000 - 500,000 inhabitants - 34.6\%. In 2011 and 2012 , in towns with $20,000-50,000$ inhabitants it was $32.5 \%$ and $39.6 \%$, respectively. In all the analysed years, place of residence did not have a significant impact on the results regarding smoking (Tab. 1).
Table 1. Percentage of smokers, age, education and place of residence in 2010-2012

\begin{tabular}{|c|c|c|c|}
\hline & 2010 & 2011 & 2012 \\
\hline Total & $30.4 \%$ & $29.8 \%$ & $30.8 \%$ \\
\hline \multicolumn{4}{|l|}{ Age } \\
\hline $18-24$ years & $23.7 \%$ & $24.2 \%$ & $35.0 \%$ \\
\hline $25-34$ years & $33.2 \%$ & $29.7 \%$ & $26.3 \%$ \\
\hline $35-44$ years & $37.8 \%$ & $33.0 \%$ & $39.6 \%$ \\
\hline $45-54$ years & $36.7 \%$ & $42.8 \%$ & $39.5 \%$ \\
\hline $55-64$ years & $35.1 \%$ & $32.9 \%$ & $34.4 \%$ \\
\hline 65 years and older & $15.8 \%$ & $16.3 \%$ & $13.1 \%$ \\
\hline Significance level for age & $\mathrm{p}<0.001$ & $p<0.001$ & $\mathrm{p}<0.001$ \\
\hline \multicolumn{4}{|l|}{ Education } \\
\hline Elementary & $27.9 \%$ & $26.2 \%$ & $35.0 \%$ \\
\hline Vocational & $40.4 \%$ & $41.3 \%$ & $36.3 \%$ \\
\hline Secondary & $28.2 \%$ & $29.8 \%$ & $30.1 \%$ \\
\hline University degree & $22.6 \%$ & $18.8 \%$ & $20.0 \%$ \\
\hline Significance level for education & $\mathrm{p}<0.001$ & $p<0.001$ & $\mathrm{p}<0.005$ \\
\hline \multicolumn{4}{|l|}{ Place of residence } \\
\hline Village & $27.9 \%$ & $28.8 \%$ & $26.9 \%$ \\
\hline Town with up to 19,999 residents & $29.0 \%$ & $29.4 \%$ & $30.5 \%$ \\
\hline Town with $20,000-49,999$ inhabitants & $33.6 \%$ & $32.5 \%$ & $39.6 \%$ \\
\hline City with $50,000-99,999$ inhabitants & $33.3 \%$ & $31.6 \%$ & $31.0 \%$ \\
\hline City with $100,000-499,999$ inhabitants & $34.6 \%$ & $29.1 \%$ & $32.3 \%$ \\
\hline City with over 500,000 inhabitants & $30.3 \%$ & $31.6 \%$ & $33.0 \%$ \\
\hline Significance level for place of residence & $p=0.623$ & $\mathrm{p}=0.955$ & $p=0.226$ \\
\hline
\end{tabular}

Attitude of Poles to the smoking ban in public places. Between 2010-2012, an increase was observed in the percentage of people supporting the smoking ban in public places. The total number of people who definitely or rather supported the smoking ban increased from $75.6 \%$ in 2010 to $83.2 \%$ in 2011 , and to $85.0 \%$ in 2012 (Fig. 2). The changes in support were statistically significant $(\mathrm{p}<0.001)$.

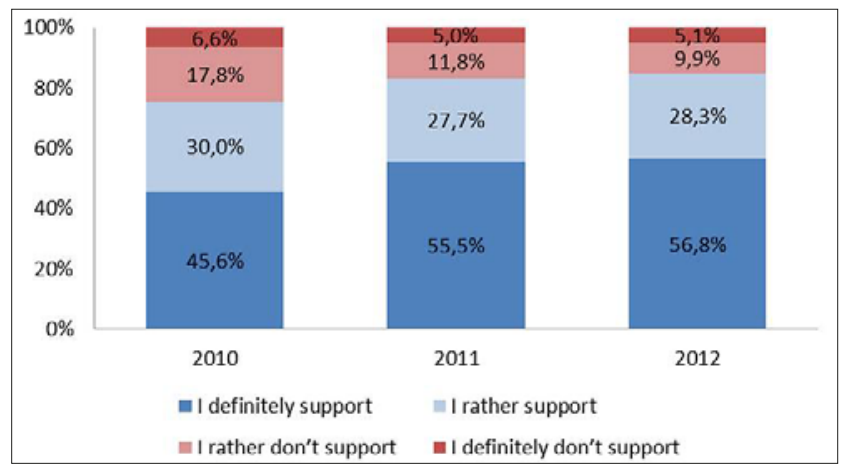

Figure 2. Percentage of people supporting the smoking ban in public places

Among the respondents who approved of the legal regulations regarding the smoking ban in public places, women were prevalent. In $2010-81.4 \%$, in $2011-89 \%$, in $2012-88.4 \%$ of women supported this. The support among men was $69.4 \%, 77.0 \%, 81.3 \%$, respectively. The differences were statistically significant in both groups $(\mathrm{p}<0.001)$.

The smoking ban in public places was most appreciated in the group aged 65 years and older. In 2010, 86.3\% of people 
at that age definitely or rather supported the ban. In 2011, it was $90.7 \%$, and in $2012-89.0 \%$. In 2010, the lowest support for the ban was noted in the group of people aged $25-34$ years $-70.8 \%$, in the group of people aged $18-24$ years $-76.7 \%$, and in 2012 , those $55-64$ years $-80.6 \%$ (Fig. 3 ).

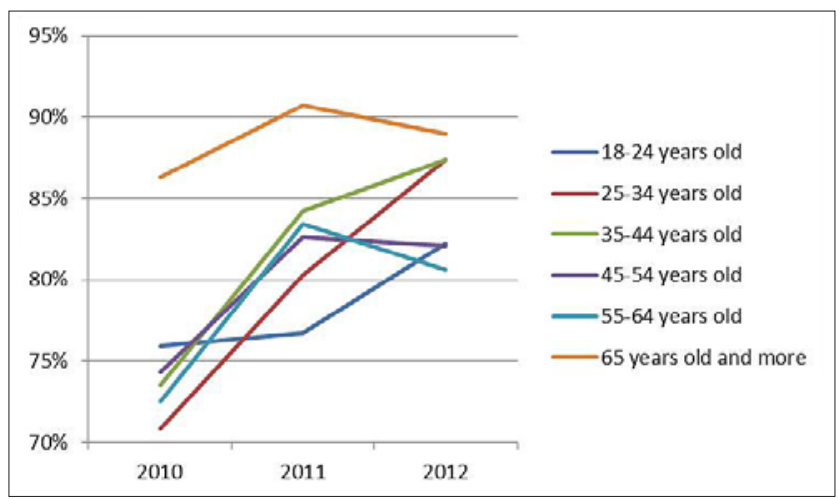

Figure 3. Percentage of people supporting the smoking ban in public places by age

The change in attitude to support the smoking ban in public places was statistically significant in the group aged $25-34$ years $(\mathrm{p}<0.001), 35-44$ years $(\mathrm{p}<0.005), 55-64$ years $(\mathrm{p}<0.05)$. In other groups the observed changes were not statistically significant.

The greatest percentage of people supporting the smokefree policy in 2010 had elementary education - 83.1\%. In the following year, support in this group increased by $1.4 \%$ percentage points, while in 2012 , it decreased by $7.7 \%$ percentage points - to $76.8 \%$. Support for the Act increased each year among people with a university degree, reaching the highest level in 2011 and 2012 at $88.8 \%$ and $92.6 \%$ (Fig. 4).

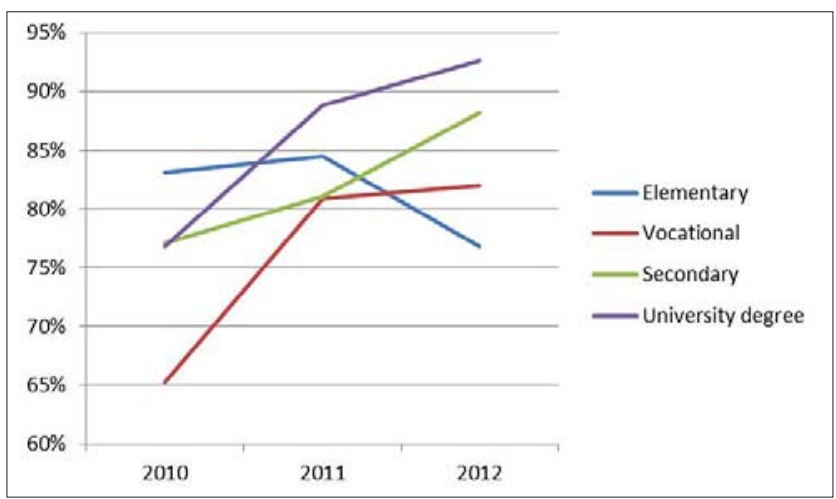

Figure 4. Percentage of people supporting the smoking ban in public places by education

In all education groups (excluding elementary education), the differences between the editions of the study were statistically significant. The significance level for vocational education was $\mathrm{p}<0.001$, secondary $\mathrm{p}<0.005$ and university degree $\mathrm{p}<0.001$.

In the analysed period, support for the smoking ban in public places among smokers was $62.1 \%$, whereas among non-smokers it was $89.7 \%$ (Fig. 5). The differences between the years were statistically significant. The significance level among smokers was $\mathrm{p}<0.005$, and among non-smokers $\mathrm{p}<0.001$.

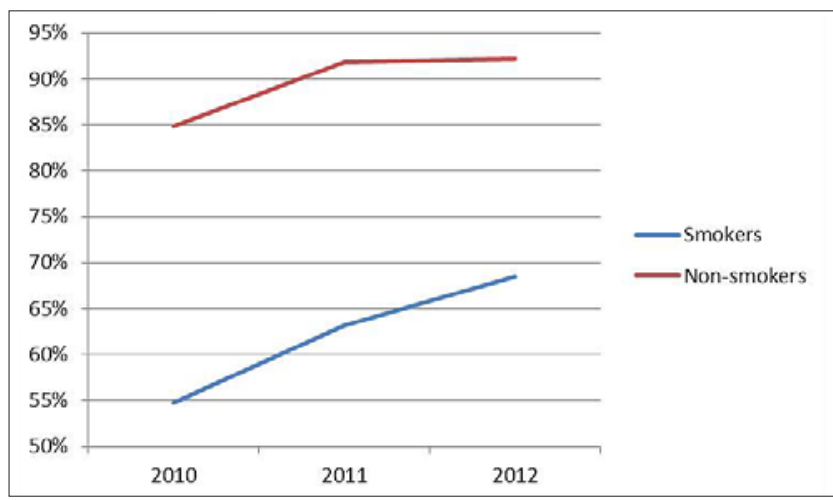

Figure 5. Percentage of people supporting the smoking ban in public places, by smokers and non-smokers

\section{DISCUSSION}

Results of the analyses show that the percentage of adult Polish smokers did not change in the period from February 2010 - July 2012, although some fluctuations were observed in 2011. Generally, the percentage of smokers during 3 year period remained at the level of about $30 \%(29.8 \%-30.8 \%)$. In the period studied, $38 \%(35.1 \%-40.3 \%)$ of men, and about $23 \%(21.4 \%-25 \%)$ of women smoked.

The National Multicentre Health Survey conducted between 2003-2005 [22] recorded 42\% of male and 25\% of female smokers [23]. Other data were presented by the Central Statistical Office [GUS - Główny Urząd Statystyczny] in the national health surveys carried out in 2004 and 2009, i.e. before implementation of the smoking ban in public places. A decrease was observed in the percentage of men and women who smoked every day, from $34 \%$ to $31 \%$ and from $19 \%$ to $18 \%$, respectively [24].

The universal character of the addiction recorded in the study was similar to the results obtained by researchers dealing with the Global Adult Tobacco Survey project at the turn of 2009 and $2010[9,10]$. The study was organised by the Centres for Disease Control and Prevention (CDC) and the WHO. In Poland, 3 institutions were responsible for its execution: the Department of Environmental Hazard Prevention and Allergology at the Medical University in Warsaw, the Maria Sklodowska-Curie Memorial Cancer Centre and Institute of Oncology, and Pentor Research International [14, 25]. The collected data show that the percentage of smokers aged 15 years and older was $30.3 \%$ (36.9\% men and $24.4 \%$ women). $27 \%$ of adults used tobacco every day $[14,15]$. Among men, the highest percentage of smokers (i.e. smoking every day and occasionally) was observed in the age group of 40-49 years $-45.3 \%$. The lowest percentages were recorded in age groups 15-19 years and 60 years and older, both $23.4 \%$. Among women, the highest percentage of smokers was noted in the age group 50-59 years at $37.4 \%$, the lowest in the age group of 60 years and older at $10 \%$ [9].

In August 2013, researchers from the Chief Sanitary Inspectorate [Główny Inspektorat Sanitarny - GIS] and TNS Poland also conducted a study regarding the attitude of Poles towards smoking. The report shows that the number of daily smokers had decreased between 2009 - 2013. The results differ from those obtained by the authors of the presented study, particularly where male smokers are concerned. 
The aforementioned data demonstrate that the total number of smokers in Poland had changed slightly from 2003. It had not changed significantly by 2013.

The differences between particular studies may result from survey questioning about smoking, different ways of conducting the study, and the age of respondents. The participants of the study carried out by CBOS were 18 years and over, whereas the participants of the Global Adult Tobacco Survey (GATS) and GIS, as well as the TNS study - 15 years and older [9, 24, 27, 28, 29]. Besides, the data regarding smoking have a declarative character, which is a limitation of the study.

The results of a public survey conducted in 2011 by the Cancer Center and Institute in Warsaw and TNS Poland showed that 1 million smokers in Poland tried to stop smoking or had quit smoking [30]. Nevertheless, one cannot exclude that the number of cigarettes smoked had decreased, which was not analysed. Similarly, exposure to second-hand smoke was not verified. These issues shall be subjected to further analyses.

Reducing the phenomenon of smoking has been influenced not only by the issue regarding the implementation or expansion of the ban, but also by increasing excise duty, and thus, the prices of tobacco products. The current excise tax accounts for about $2 / 3$ of the price of cigarettes, which led to higher prices of cigarettes. However, the prices of cigarettes in Poland are still low among the EU countries. In addition, a fast-growing Polish economy has caused an increase in the affordability of tobacco products. Thus, the excise tax and cigarette prices should continue to be increased [30].

It is advisable to regularly monitor social changes regarding smoking, which would also include smokers' declarations concerning the number of smoked cigarettes. Monitoring non-smokers' exposure to tobacco smoke is of equal importance. One will probably have to wait for real improvement as quitting smoking (and most smokers use tobacco regularly) is difficult and often requires many attempts.

On the basis of observations it cannot be concluded that the smoke-free policy did not affect the incidence of smoking. The analysis was limited to selected variables. This phenomenon is complex and multidimensional. There is a risk that factors not included in the study influenced significantly on the percentage of smokers in Poland and the support for the smoking restrictions in public places (e.g. changes in the social structure, running social campaigns, the price of cigarettes, etc.). This is the main limitation of the study.

In the analysed period, an increase in the percentage of people expressing their support for the anti-smoking policy was recorded. The total share changed from $2010-73.8 \%$, in $2011-81.7 \%$ to $83.7 \%$ in 2012 . Increased support was also observed in the groups of smokers and non-smokers. In the group of non-smokers - by 7.4 percentage points, from $84.8 \%$, in the group of smokers - by 13.7 percentage points, from $54.8 \%$ in 2010 . Similar to Poland, increased support was observed in other Member States. In Italy, it increased gradually from $83 \%$ before implementation of the ban in 2001, to $93 \%$ in 2006, after implementation [16]. The issue regarding tobacco smoking and support for new laws was also monitored in Ireland. The social changes in the period before and after implementation of the ban in public places and the workplace were analysed. Change of the support for implemented changes among smokers was checked at the turn of 2003 and 2004 - before legislation changes, and at the turn of 2004 and 2005. The support for a complete smoking ban in the workplace increased from $43 \%$ to $67 \%$, in restaurants - from $45 \%$ to $77 \%$, and in bars - from $13 \%$ to $46 \%$ [31]. In Finland, support for the antitobacco policy in restaurants increased from 34\% in 2004 to $61 \%$ in 2005 . Similar results were achieved in Norway, where support for tobacco-free zones in restaurants and bars was 54\% in 2004, and 90\% in 2011 [16]. In Poland, support for the smoking ban also increased significantly by 10 percentage points in the period of 2 years, which is a positive result. Despite controversies around implementation of the new legal regulations, they were well received by the majority of society. This shows that the way taken by the Polish authorities was right and approved by society. One should hope that the changes will also decrease the number of smokers in Poland in the long run.

Smoking is not only a big problem from the point of view of public health, but it is also a serious social problem. Therefore, this issue should be one of the priorities for health policy in Poland.

\section{CONCLUSIONS}

1. The percentage of smokers did not change significantly between 2010-2012. However, an increase in the number of people supporting the smoking ban in public places was observed.

2. There is a need to continue the nationwide education that will increase awareness of the risks and negative impact on health.

3. Raising cigarette prices and restrictions on smoking in public places has not produced the expected results in reducing the percentage of regular smokers. It is necessary to conduct further qualitative and quantitative research in order to develop more effective methods for influence on this group of people.

\section{Acknowledgments}

The study was carried out within the framework of a research project which ran from 2013 until 2014, funded by a grant statutory obtained by the Division of Health Sciences, Medical University of Warsaw.

\section{REFERENCES}

1. U.S. Department of Health and Human Services. A report of the Surgeon General: How tobacco smoke causes disease: What it means to you. U.S. Department of Health and Human Services, Centers for Disease Control and Prevention, National Center for Chronic Disease Prevention and Health Promotion, Office on Smoking and Health; 2010.

2. Gandini S, Botteri E, Iodice S, et al. Tobacco smoking and cancer: A meta-analysis. Int J Cancer 2008; 122: 155-164.

3. Giovino GA, Mirza SA, Samet JM, et. al. Tobacco use in 3 billion individuals from 16 countries: an analysis of nationally representative cross-sectional household surveys. Lancet. 2012; 380: 668-679.

4. WHO. Global health risks: mortality and burden of disease attributable to selected major risks.: http://www.who.int/healthinfo/global_burden_ disease/GlobalHealthRisks_report_full.pdf (accessed August 1, 2015).

5. World Health Organization. WHO Report on the Global Tobacco Epidemic, 2011 - Warning about the dangers of tobacco. Geneva: WHO; 2011.

6. Zatoński W, Przewoźniak K, Sulkowska U, West R, Wojtyła A. Tobacco smoking in countries of the European Union. Ann Agric Environ Med. 2012; 19(2): 181-192. 
7. Jha P. The 21st century benefits of smoking cessation in Europe. Eur J Epidemiol. DOI 10.1007/s10654-013-9835-6

8. Kaleta D, Kozieł A, Miśkiewicz P. Globalne badanie dotyczące używania tytoniu przez osoby dorosłe (Global Adult Tobacco Survey - GATS) w Polsce - cel i dotychczasowe doświadczenia. Med Pr. 2009; 60(3): 197-200.

9. Kaleta D, Kamowiec-Dąbrowska T, Dziankowska-Zaborszczyk E, Fronczak A. Determinants of heavy smoking: results from the Global Adult Tobacco Survey In Poland (2009-2010). Int J Occup Environ Health. 2012; 25(1): 66-79.

10. Kaleta D, Polańska K, Wojtysiak P, et al. Effective protection from exposure to environmental tobacco smoke in Poland: the World Health Organization perspective. Int J Occup Environ Health. 2010; 23(2): 123-131.

11. http://www.cdc.gov/tobacco/data_statistics/fact_sheets/health_effects/ effects_cig_smoking/index.htm (accessed August 1,2015)

12. Pierzchała W, Barczyk A, Górecka D, Śliwiński P, Zieliński J. Zalecenia Polskiego Towarzystwa Chorób Płuc rozpoznawania i leczenia przewlekłej obturacyjnej choroby płuc (POChP). Pneumonol Alergol Pol. 2010; 78(5): 318-347

13. Chiosi JJ, Andes L, Asma S, Palipudi K, McAfee T. Warning about the harms of tobacco use in 22 countries: findings from a crosssectional household survey. Tob Control 2015; 0:1-9. (doi:10.1136/ tobaccocontrol-2014-05204)

14. Ministerstwo Zdrowia. Globalny Sondaż dotyczący Używania Tytoniu przez Osoby Dorosłe (GATS). Polska 2009-2010. Warszawa: Ministerstwo Zdrowia; 2010.

15. Włodarczyk A, Raciborski F, Opoczyńska D, Samoliński B, GATS PWG. Daily tobacco smoking patterns in rural and urban areas of Poland - the results of the GATS study. Ann Agric Environ Med. 2013; 20(3): 588-594.

16. Commission Staff Working Document. Report on the implementation of the Council Recommendation of 30 November 2009 on Smoke-free Environments (2009/C 296/02). Brussels: European Commission; 2013.

17. Ustawa z dnia 9 listopada 1995 r. o ochronie zdrowia przed następstwami używania tytoniu i wyrobów tytoniowych (Dz.U. $1996 \mathrm{nr} 10$ poz. 55, z pozn. zm.)

18. Uchwała Nr 90/2007 Rady Ministrów z dnia 15 maja 2007 r. w sprawie Narodowego Programu Zdrowia na lata 2007 - 2015.
19. Stankiewicz-Choroszucha B, Wawrzyniak Z, Lipiec A, Piekarska B, Kapalczynski W, Samoliński B. Consequences of smoke inhalation in the 'Epidemiology of Allergic Diseases in Poland' project (ECAP). Ann Agr Env Med. 2011; 18(2): 420-428.

20. Smith AK, Ayanian JZ, Covinsky KE, et al. Conducting High-Value Secondary Dataset Analysis: An Introductory Guide and Resources. J Gen Intern Med. 2011; 26(8): 920-929.

21. Cheng HG, Phillips MR. Secondary analysis of existing data: opportunities and implementation. Shanghai Arch Psychiatry. 2014; 26(6): 371-375.

22. http://wobasz-projekt.pl/index.php/badanie-wobasz-ii/opis-badania (accessed April 28, 2015)

23. Polakowska M, Piotrowski W, Tykarski A, et al. Nałóg palenia tytoniu w populacji polskiej. Wyniki programu WOBASZ. Kardiol Pol. 2005; 63(4):1-9.

24. Główny Urząd Statystyczny. Stan Zdrowia Ludności Polski w 2009 r. Warszawa; 2011.

25. Kaleta D, Usidame B, Biliński P, et al. Global Adult Tobacco Survey (GATS) in Poland 2009-2010 - study strengths, limitations and lessons learned. Ann Agric Environ Med. 2012; 19(4): 717-722.

26. TNS Polska dla Głównego Inspektoratu Sanitarnego. Raport z ogólnopolskiego badania ankietowego na temat postaw wobec palenia tytoniu. Warszawa; 2013.

27. Centrum Badania Opinii Społecznej (CBOS). Komunikat z badań: Postawy wobec palenia papierosów. BS/36/2012. Warszawa; 2010.

28. Centrum Badania Opinii Społecznej (CBOS). Komunikat z badań: Postawy wobec palenia papierosów. BS/70/2011. Warszawa; 2011.

29. Centrum Badania Opinii Publicznej (CBOS). Komunikat z badań: Postawy wobec palenia papierosów. BS/107/2012. Warszawa; 2012.

30. Jassem J, Przewoźniak K, Zatoński W. Tobacco control in Polandsuccesses and challenges. Transl Lung Cancer Res 2014; 3(5): 280-285.

31. Fong GT, Hyland A, Borland R, et al. Reductions in tobacco smoke pollution and increases in support for smoke-free public places following the implementation of comprehensive smoke-free workplace legislation in the Republic of Ireland: findings from the ITC Ireland/ UK Survey. Tob Control. 2006; 15(3): iii51-iii58. 